\title{
Notes on Some Customs of the Bangala Tribe, Upper Congo
}

\section{J. H. Weeks}

To cite this article: J. H. Weeks (1908) Notes on Some Customs of the Bangala Tribe, Upper Congo, Folklore, 19:1, 92-97, DOI: 10.1080/0015587X.1908.9719816

To link to this article: http://dx.doi.org/10.1080/0015587X.1908.9719816

曲 Published online: 14 Feb 2012.

Submit your article to this journal $\pi$

Џll Article views: 1

Q View related articles $\longleftarrow$ 


\section{A Pin-Offering.}

The following excerpt from the Church Times of Sep. 1 3th, 1907, is, I think, worth recording. The writer after giving some description of the Norman building called St. Aldhelm's Chapel, Worth, Isle of Purbeck, goes on to say: "Mr. Moule tells us that, during the time of its dilapidation, it was the custom of the parishioners of Worth, on Thursday in Whitweek, to visit this building, deck it with flowers, and dance therein; it used at that time to pass by the name of the Devil's Chapel. There was an old custom, still maintained, of placing a pin in an opening of the central shaft, accompanying the action with a silently expressed wish. When visiting the building on two occasions last August, about a dozen pins were noticed in the aperture, which is not to be wondered at, since all the cheap guide-books exploit its fame in this direction. On my last visit a young lady, apparently of some refinement and education, entered the fabric, at once proceeded to the pin-hole, and deposited her contribution, at the same moment closing her eyes with a rapt expression of countenance, whilst her lips moved as she mutely made her wish."

\section{G. Montagu Benton.}

Cambridge University Museum.

\section{Notes on Some Customs of the Bangala Tribe, UPPER CONGo.}

I. DURINg the first few hours after the death of a woman nearly all her female neighbours cry as though their hearts were broken, but the next day they commence dancing, and continue to do so at short intervals, for five or six days. The husband hires a professional dancer to act as master of the ceremonies.

II. In the farm of the dead woman a ring is made by throwing up a bank of earth, and in this ring are placed the saucepans, hoes, mats, and private property of the deceased, together with. 
her farm produce. No one would think of using the goods, etc., belonging to a dead person.

III. One day I saw an old woman whom I knew very well sitting in the centre of a ring of fire, and upon inquiry I found that she had had much to do with preparing a corpse for burial, and at the close of the ceremony she was purified by the fire being lit around her. In my unpublished Dictionary of the Ngala language I have the following word and its explanation: "Tumbujela, to purify a person who has touched a dead body by fire. A ring of fire made of small sticks encircles the person, who takes a leaf, dries it, crushes it in the fist, and sprinkles it on the fire, moving the hands over the fire ring; when the fire goes out the nganga takes hold of the person by the little finger and lifts his or her arm (amobili loboko), and the person comes from the fire-circle purified."

IV. Walking one day in the Monsembe village I saw an incident that recalled Tam o' Shanter to my mind. There had been a death in the family, and the relatives had just performed all the necessary rites and ceremonies, and were returning to their houses. A small trench some 20 feet long was dug with a hoe. The relatives took up their position on the side of the trench nearest to the new grave, the nganga (witch-doctor) stood on the other side, and his assistant was placed at the end of the trench with a large calabash of water. At a signal the water was poured into the trench, and while it was running the nganga took each person by the hand and, mumbling an in. cantation, pulled him or her over the running water. When all had been pulled over one by one the water was allowed to continue to run until the calabash was empty. I asked the reason of the ceremony, and they told me that it was to keep the spirit of their buried relative from following them.

V. The favourite mediæval mode of injuring an enemy by sticking pins into his image is represented on the Upper Congo. This I discovered through two men quarrelling outside ny house at Monsembe. On inquiring into the cause of the quarrel, $A$ told me that it had been reported to him that $B$ had visited a witchdoctor in the bush-town, and had paid him to boil a saucepan of "medicine" and to call up his ( $A$ 's) image in the saucepan, and 
then he $(B)$ had repeatedly stabbed the image. So $A$ charged $B$ with wanting to cause his death. $B$ denied the charge and wished $A$ to go with him to the witch-doctor, who would tell him that he did not stab $A$ 's image but someone else's.

VI. A few days ago ${ }^{1}$ I had the opportunity of seeing a rather complicated discussion and cross-accusation settled to the satisfaction of all the natives present by the parties concerned drinking, or rather eating, the ordeal.

The trial took place on neutral ground, i.e. in a section of the town midway between the sections in which the parties concerned lived. The court house was a wide-spreading wild fig-tree that cast a shade over the whole gathered crowd, which formed an oblong figure. The plaintif stood at one end with his supporters, the defendant at the other with his, and the two sides were occupied by neutrals and sympathisers. The case was as follows: The plaintiff had two slaves who ran away, and after some days he heard that these slaves had gone away in a canoe belonging to the defendant, so he accused the latter of aiding and abetting their escape, and wanted him to pay him for them. The defendant, on the other hand, wanted the plaintiff to pay him back a canoe or the price of it, as he said it had been stolen by the plaintiff's slaves. For three hours they discussed the matter and tried to arrange an amicable compromise. This, however, was impossible, as each wished to get the best of the bargain. From the nature of the case it was impossible to call witnesses, although many persons spoke on either side. At last it was decided that the parties should take the $n k a$ (ordeal drug). Each was so confident of the righteousness of his claims that he was willing and eager to eat a portion of the poisonous drug to support it. The plaintiff was a short, thick-set young man troubled with elephantiasis, and from that and his apparent nervousness he was greatly handicapped in the trial. The defendant was a tall, thin, wiry man about fifty years of age, who had, I think, often taken the $n k a$ before, and was inured to it.

The $n k a$ is the outer skin of the rootlets of a tree that grows up the Lulanga River-a tributary that enters the Congo River 1 Written in 1894. 
on the south some forty miles below the Monsembe district. It is very fluffy, and of a deep scarlet colour. Two ngangas prepared equal portions of the $n k a$. There was about a dessertspoonful in each portion. The accused had first choice, after which each doctor with the portion of $n k a$ in the palm of his hand took up his position by the side of his client, and at a given signal the portions of $n k a$ were simultaneously held to the mouths of the two opponents, and at the same moment they began to chew the drug. After chewing for a few moments each washed it down with gulps of sugar-cane wine.

After taking the ordeal, the men are allowed neither to sit down nor to lean against anything, nor even to touch anything with their hands. The $n k a$ given in the above quantity blurs the vision, distorting and enlarging all objects, makes the legs tremble, the head giddy, and gives a choking sensation in the throat and chest. In fact it gives all the symptoms of intoxication and $a$ few more besides. The one who first becomes intoxicated and falls down is the loser, and the one who resists the effects of the drug and controls himself the longest is the winner.

About five minutes after they had taken the ordeal, a native doctor stepped into the centre with a plantain stalk in his hand, about two feet six inches long and three inches to four inches diameter. He fourished this stalk about a little, and then placed it in front of the plaintiff for him to step over. He went forward boldly, stepped over it, and returned to his place. This was repeated six times without his feet once touching the stalk. The defendant had then to go through the same test, which he did laughingly, throwing his arms and legs about in all directions. This was done occasionally for the next thirty minutes, and the plaintiff (the accuser) began to show signs of intoxication. His steps faltered, his eyes brightened and glared, and it was with difficulty that he raised his feet over the stalk. Then the "doctor" began to mock him, pretending to put the stalk close to his feet and tantalizingly drawing it back. Forty minutes after taking the $n k a$ the climax came. The "doctor" threw the stalk to the defendant (the accused), who caught it in his hands and carried it to the centre, where, 
firmly fixing his feet on the ground, he stooped forward and placed the stalk with both his hands in a straight line, then raising himself he went back to his place. The plaintiff then went to pick it up, but no sooner did he lean forward than a spasm of pain seized him, and he would have fallen had not a man, who for the last twenty minutes had followed him closely, caught him in his arms and quickly carried him to his house.

No sooner did the crowd of neutrals see the fall of one of the opponents than with a bound they jumped to their feet; and with spears and knives raised in the air they danced, shouted, and sang around the winner. Some rubbed dirt, others ashes, and others red-camwood powder on the fellow's facea sign that he had won the case. They then hoisted him on the back of a friend and carried him home. He distributed four hundred brass rods among the crowd of his admirers, who said they had helped him to win his cause. He sat outside his hut all the rest of the day with his face smeared, so that all could see he had won, and could congratulate him. The plaintiff had to pay him two slaves and a canoe as damages.

The next day both accused and accuser were walking about the town, and seemed none the worse for drinking so powerful and dangerous a narcotic. They apparently had no enmity towards each other, but chatted freely and laughingly over the events of the previous day.

When one remembers the amount of corruption and bribery among these people; that the most familiar words on their lips are "lie," "liar," and that the most frequent question is, "Is it true?" and the answer, "It is true or cut my throat," - the wonder is that they can settle a palaver in any way.

To drink the ordeal and be either right or wrong according to its action settles the affair once for all, ends all possible deadly feuds and bloodshed, and saves many a man from what is worse than death, viz. an ever-present anxious fear of what his enemy or enemies may do to him. If a man accuses another - giving him a disease, or of causing the death of his wife by witchcraft, how can the accused disprove such a charge? Not by talking, no matter how much he may swear that he is innocent. If he calls the chiefs and headmen together he knows 
the verdict will be given in favour of the one who pays the most; if he runs away he will soon be captured by some other town, and probably sold to furnish a cannibal feast; if he runs to a friendly town he will lose caste, he will be treated with contempt as a coward, and his life be rendered miserable. So he boldly steps forth and takes the $n k a$, and the affair is settled. Is the ordeal in his favour? Then he claims and gets heavy damages. Does the ordeal go against him? Then he pays the damages, if wealthy enough; or, if poor, sells himself; or, if a slave, his master pays for him. But whatever be the result, that palaver is decided once for all.

No stigma attaches to a man who is found guilty, for "one can have witchcraft without knowing it." Moreover, no one lightly brings a charge of witchcraft against another, for, if the ordeal test goes against the accuser, the damages are so very heavy as to deter frivolous accusations.

Congo Free State.

J. H. WEEKS. 